\title{
Quality Attributes of Fresh-Cut Coconut after Supercritical Carbon Dioxide Pasteurization
}

\author{
Giovanna Ferrentino, ${ }^{1}$ Ana Belscak-Cvitanovic, ${ }^{2}$ Drazenka Komes, ${ }^{2}$ and Sara Spilimbergo ${ }^{1}$ \\ ${ }^{1}$ Department of Materials Industrial Engineering, University of Trento, Via Mesiano 77, 38123 Trento, Italy \\ ${ }^{2}$ Department of Food Engineering, Faculty of Food Technology and Biotechnology, University of Zagreb, Pierottijeva 6, \\ 10000 Zagreb, Croatia \\ Correspondence should be addressed to Sara Spilimbergo; sara.spilimbergo@ing.unitn.it
}

Received 11 February 2013; Accepted 21 May 2013

Academic Editor: Marleny D. A. Saldaña

Copyright (C) 2013 Giovanna Ferrentino et al. This is an open access article distributed under the Creative Commons Attribution License, which permits unrestricted use, distribution, and reproduction in any medium, provided the original work is properly cited.

\begin{abstract}
The impact of supercritical $\mathrm{CO}_{2}\left(\mathrm{SC}-\mathrm{CO}_{2}\right)$ process on the quality attributes of fresh-cut coconut has been investigated to establish the acceptability of SC- $\mathrm{CO}_{2}$ treated products by the consumers. Two process conditions, previously identified as optimal to reduce the microbial content of the product, were studied: $12 \mathrm{MPa}, 40^{\circ} \mathrm{C}, 30 \mathrm{~min}$ and $12 \mathrm{MPa}, 45^{\circ} \mathrm{C}, 15 \mathrm{~min}$. The results highlighted that both conditions induced some effects on product attributes. After $30 \mathrm{~min}$ of treatment at $12 \mathrm{MPa}$ and $40^{\circ} \mathrm{C}$ a decrease of lightness (8\%), $\mathrm{pH}(13 \%)$, fat content (24\%), total phenol content (29\%), flavonoid compounds (49\%), antioxidant capacity ( $30 \%)$ and an increase of dry matter (11\%) and titratable acidity (51.1\%) were observed while polyphenol oxidase (PPO) exhibited 35\% and $98.5 \%$ inactivation. Peroxidase enzyme activity increased by $77.8 \%$ and $30.4 \%$ at $12 \mathrm{MPa}, 40^{\circ} \mathrm{C}, 30 \mathrm{~min}$ and $12 \mathrm{MPa}, 45^{\circ} \mathrm{C}, 15 \mathrm{~min}$, respectively. Sensory evaluations revealed no significant differences in appearance, texture, taste, and aroma of treated fresh-cut coconut compared to the untreated. The study confirms the feasibility of $\mathrm{SC}-\mathrm{CO}_{2}$ process for the pasteurization of fresh fruits with a firm structure and opens the door to the possibility of exploiting such a technology at industrial level.
\end{abstract}

\section{Introduction}

Fresh-cut fruits and vegetables, fresh raw products, are processed to supply ready-to-eat or ready-to-use foods [1,2]. They are becoming popular within the consumers who demand hygienically safe [3] and economically convenient products, with fresh-like characteristics. Coconut (Cocos nucifera L.) prepared as fresh-cut fruit to be eaten and served as a snack is gaining great appeal; however, the operations for its production such as cutting and washing could fasten the microbial growth and accelerate enzymes' actions, shortening its shelf-life in comparison with the fresh product [4]. To avoid or retard microbial and enzymatic spoilage of the product reducing or minimally compromising its quality aspects, while maintaining a fresh appearance, its original flavor and texture, several treatments are currently under investigation such as sodium chloride treatments [5]; steam blanching [6]; immersion in acid or basic solutions [7]; and use of modified atmosphere packaging [8].
Supercritical carbon dioxide $\left(\mathrm{SC}-\mathrm{CO}_{2}\right)$ is a promising alternative process potentially able to inactivate microorganisms and enzymes in liquid foods with minimal effects on phytochemicals and organoleptic characteristics. The main advantage of the technique consists of the relatively low temperature which avoids the thermal effects of the traditional heat pasteurization, retaining the food freshness in terms of physical, nutritional, and sensory qualities [9]. Concerning solid foods, the research is still at its infancy: few papers have been published so far in the field [10]. A deleterious effect in terms of gross tissue destruction on strawberries, honeydew melon, cucumber [11], and pear [12] which negatively influenced product aspect, discouraging the application of the technology to products with soft structures, was reported. Differently, Ji et al. [13] demonstrated that shrimps $\mathrm{CO}_{2}$ processed gained a cooked appearance, positively accepted by the panelists, and proved that these changes could be attractive for shrimps consumption in the Chinese diet custom. Their findings demonstrated that modifications of the product 
appearance could not be a restraint but an improvement in the development of an innovative pasteurization technique, depending on people and cultural habits.

As concerns fresh-cut coconut, one study has been recently published to assess the effectiveness of $\mathrm{SC}-\mathrm{CO}_{2}$ as nonthermal technique for the pasteurization of such a product, assuring its microbial safety. The results clearly demonstrated the potential of $\mathrm{SC}-\mathrm{CO}_{2}$ pasteurization of freshcut coconut which significantly reduced total mesophilic microorganisms, total coliforms, yeasts and molds, and lactic acid bacteria naturally present on its surface. The optimal process conditions identified were $12 \mathrm{MPa}, 40^{\circ} \mathrm{C}, 30 \mathrm{~min}$ and $12 \mathrm{MPa}, 45^{\circ} \mathrm{C}, 15 \mathrm{~min}$ at which $4 \mathrm{Log}(\mathrm{CFU} / \mathrm{g})$ reductions were achieved for the mentioned microbial strains [14].

At this stage the investigation of the impact of such technology on the quality attributes of the product is needed in view of a possible development of $\mathrm{SC}-\mathrm{CO}_{2}$ process at industrial scale. In this concern, the aim of the present study is the evaluation of the effects of $\mathrm{SC}-\mathrm{CO}_{2}$ process on the quality attributes of fresh-cut coconut in terms of color, $\mathrm{pH}$, titratable acidity (TA), fat content, dry matter (DM), indigenous enzyme activity, total phenol content (TPC), flavonoid compounds (FC), antioxidant capacity, and sensory attributes (aroma, taste, appearance, and texture).

\section{Materials and Methods}

2.1. Sample Preparation. Coconut (Cocos nucifera) was purchased from a local market, deshelled, cleaned, washed with water, and manually cut in pieces. The samples were transferred into the reactor and treated at $12 \mathrm{MPa}, 40^{\circ} \mathrm{C}$ for $30 \mathrm{~min}$ and $12 \mathrm{MPa}, 45^{\circ} \mathrm{C}$ for $15 \mathrm{~min}$. The process conditions were chosen on the basis of the previous study on microbial inactivation [14]: they assured the highest pasteurizing effect (4.7 log reductions of mesophilic microorganisms, $2.6 \mathrm{log}$ reductions of lactic bacteria, $4.6 \mathrm{log}$ reductions of total coliforms, and $3.2 \mathrm{log}$ reductions of yeasts and molds) on the natural microbial flora occurred on fresh-cut coconut.

2.2. High Pressure Carbon Dioxide Equipment. SC- $\mathrm{CO}_{2}$ treatment was performed in the batch apparatus shown in Figure 1. Liquid $\mathrm{CO}_{2}$ (99.990\% purity, Messer Group $\mathrm{GmbH}$, Germany) was fed into a high pressure vessel by a volumetric pump (LCD1/M910s, LEWA GmbH, Germany) with a maximum flow rate of $11 \mathrm{l} / \mathrm{h}$. The vessel consisted of a $310 \mathrm{~mL}$ stainless steel cylinder (height: $110 \mathrm{~mm}$, inner diameter: $60 \mathrm{~mm}$ ) and was equipped with a resistance temperature probe $\left(\mathrm{Pt} 100^{\prime} \Omega\right.$, Endress+Hauser, Milano, Italy) and a pressure gauge (Gefran, Brescia, Italy). The sample was loaded into the vessel, heated to a defined temperature, and subsequently pressurized with $\mathrm{CO}_{2}$. The system was kept at the process conditions of temperature and pressure for the time required for the treatment, and then slowly depressurized. Pressure and temperature were continuously recorded by a real time data acquisition system (field point FP-1000 RS 232/RS 485, NATIONAL INSTRUMENTS, Austin, Texas, USA) and monitored by a specific software (LabVIEW 5.0). The depressurization step was performed by partially opening two micrometric valves ( $2 \mathrm{~S}-4 \mathrm{~L}-\mathrm{N}-\mathrm{SS}$, Rotarex, Brescia, Italy) placed on the output line of the system, heated with an electrical resistance ( $80 \mathrm{~W}$, CSC2, Backer Fer, Ferrara, Italy) to prevent $\mathrm{CO}_{2}$ freezing during the expansion to ambient pressure. After each experimental run, the reactor was washed with water and sterilized in autoclave $\left(121^{\circ} \mathrm{C}, 15 \mathrm{~min}\right)$ to prevent possible contaminations, while $\mathrm{CO}_{2}$ was flushed at $6 \mathrm{MPa}$ through all tubes to ensure a good level of cleaning.

2.3. Color Measurements. Color parameters were measured with a high resolution miniature spectrometer (HR2000+, Ocean Optics Inc., Dunedin, FL) to which a fiber optic reflection probe (QR600-7-UV-125BX, Ocean Optics Inc., Dunedin, FL) was connected. The probe transmitted the light from a halogen lamp to the sample surface by the illuminating fibers while the reflected light from the sample was acquired by a reading fiber and measured by the spectrometer. After calibration, the sample was placed on a holding device and the signal acquired by a specific software (Spectra Suite, Ocean Optics, Dunedin, FL, USA) which provides $L^{*}$ (lightness), $a^{*}$ (redness) and $b^{*}$ (yellowness) parameters. Color analyses were performed on samples treated three times at the same process conditions and the mean values together with the standard deviations reported. Additionally, in order to quantify the overall color differences, $\Delta E$ values were evaluated based on the following equation [15]:

$$
\Delta E=\sqrt{\left(L_{1}^{*}-L_{2}^{*}\right)^{2}+\left(a_{1}^{*}-a_{2}^{*}\right)^{2}+\left(b_{1}^{*}-b_{2}^{*}\right)^{2}},
$$

where $L^{*}, a^{*}$, and $b^{*}$ with subscript numbers represent lightness, redness, and yellowness measured before and after treatments, respectively. More details of the procedure can be found elsewhere [16].

2.4. $p H$ Determination. The sample (30 grams) was homogenized with $30 \mathrm{~mL}$ of distilled water and the $\mathrm{pH}$ was measured using a digital $\mathrm{pH}$ meter (Eutech Instruments, Nijkerk, The Netherlands), after calibration with commercial buffer solutions at $\mathrm{pH} 7.0$ and 4.0. The measurements, in triplicate for each condition, were performed recording the $\mathrm{pH}$ of $10 \mathrm{~mL}$ of the homogenized solutions.

2.5. Titratable Acidity Measurements. $10 \mathrm{~mL}$ of a solution obtained from the sample ( 30 grams), homogenized with $30 \mathrm{~mL}$ of distilled water, was titrated against standardized $\mathrm{NaOH}(0.05 \mathrm{~N})$ to the phenolphthalein end point $(\mathrm{pH}=8.2 \pm$ 0.1 ). The volume of $\mathrm{NaOH}$ was converted to grams of lauric acid (considered the prevalent acid in fresh-cut coconut) per $\mathrm{mL}$ of the homogenized solution and titratable acidity (TA) calculated based on the following formula:

$$
\mathrm{TA}(\text { lauric acid } \mathrm{g} / \mathrm{L})=\frac{(\mathrm{mL} \mathrm{NaOH} \text { used }) \cdot(\text { Normality of } \mathrm{NaOH}) \cdot(\text { Molecular weight of lauric acid })}{\mathrm{mL} \text { homogenized sample }} .
$$




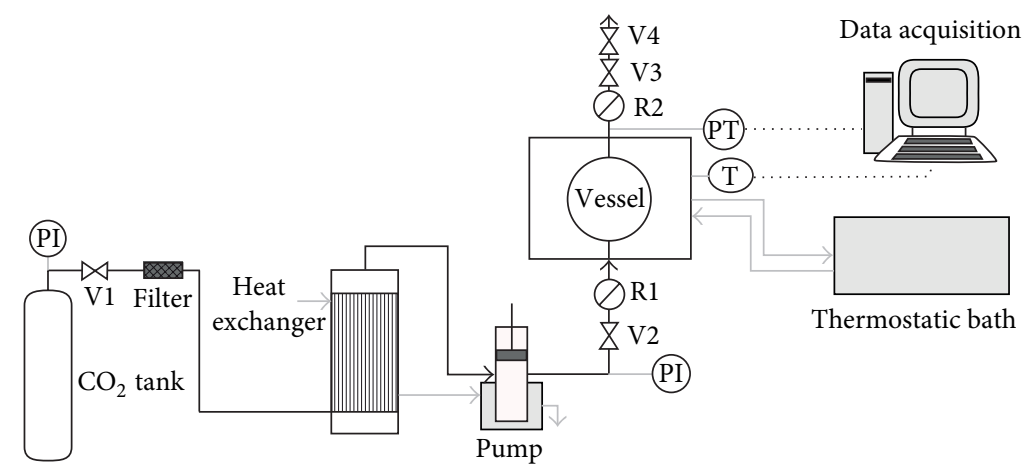

FIgURE 1: Schematic of the SC-CO $\mathrm{C}_{2}$ apparatus. V1 to V4: valves; R1, R2: electrical resistance; PT: pressure transducer; T: thermocouple; PI: pressure manometer.

Measurements were performed in triplicate and mean values and standard deviations were evaluated.

2.6. Dry Matter Content. Dry matter (DM) was determined according to the official AOAC method [17] by drying the samples at $105^{\circ} \mathrm{C}$ to reach a constant weight. The dry matter content, measured as the remaining weight of sample after drying, was expressed as percentage of the fresh sample.

\subsection{Determination of Phenolic Compounds and Antioxidant Capacity}

2.7.1. Preparation of the Samples. Fresh-cut coconut endocarp and mesocarp were ground in a domestic blender and dried in a conventional laboratory dryer for $3 \mathrm{hrs}$ at $60^{\circ} \mathrm{C}$. In order to eliminate lipids, each sample was subjected to extraction for $48 \mathrm{hrs}$ with petroleum ether using a Soxhlet apparatus [18]. The defatted samples were air-dried for $24 \mathrm{hrs}$ to remove the residual organic solvent and extracted with $20 \mathrm{~mL}$ of $50 \%$ ethanol/water solution (v/v) for $1 \mathrm{hr}$ in an ultrasonic bath (Elmasonic S 120, Elma, Singen, Germany). After extraction, the mixture was centrifuged for $10 \mathrm{~min}$ at $4000 \mathrm{rpm}$, and the supernatant was decanted and filtered to remove the residual particles and obtain $20 \mathrm{~mL}$ of extract. The flask containing the extract was flushed with nitrogen, stored in a freezer at $-18^{\circ} \mathrm{C}$, and subsequently analyzed for the determination of total phenol content (TPC) and antioxidant capacity.

2.7.2. Total Phenol and Flavonoid Content. Total phenol content (TPC) was determined spectrophotometrically according to the modified method of Lachman et al. [19]. Total flavonoids were precipitated using formaldehyde, which reacted with the hydroxyl groups at the C-6 or C-8 positions in the benzene rings of 5,7-dihydroxy flavonoids. The condensed products of these reactions were removed by filtration and the remaining nonflavonoid phenols determined, according to the procedure for total phenol content determination. Flavonoid content (FC) was calculated as the difference between total phenol and nonflavonoid content. Gallic acid was used as standard and the results were expressed as mg gallic acid equivalents (GAE)/g of DM [20].
All measurements were performed in triplicate and mean values and standard deviations were evaluated.

2.7.3. HPLC Analysis of Phenolic Compounds. Coconut extracts were analyzed for their phenolic acids content according to the IOOC [21] method with some modifications. The samples were filtered through a $0.45 \mu \mathrm{m}$ filter (Nylon Membranes, Supelco, Bellefonte, USA), and $20 \mu \mathrm{L}$ were analyzed using a HPLC device (Agilent 1100/1200 Series, Santa Clara, USA) with a Diode Array detector (scanning between 200 and $400 \mathrm{~nm}$, with a resolution of $1.2 \mathrm{~nm}$ ) and a reversedphase column $(250 \times 4.6 \mathrm{~mm}, 5 \mu \mathrm{m}$ i.d. $)$ (Nucleosil C-18, Phenomenex, Torrance, USA). The solvents used for the analyses consisted of $0.2 \%$ orthophosphoric acid (solvent A), HPLC grade methanol (solvent B), and HPLC grade acetonitrile (solvent C) at a flow rate of $1.5 \mathrm{~mL} / \mathrm{min}$. The elution was performed with a gradient starting from $2 \% \mathrm{~B}$ and $2 \% \mathrm{C}$ to reach $25 \% \mathrm{~B}$ and $25 \% \mathrm{C}$ in 40 min with a column temperature of $30^{\circ} \mathrm{C}$. Chromatograms were recorded at $280 \mathrm{~nm}$. Phenolic compounds were identified by comparing the retention times and the spectral data with the standards. Data acquisition and elaboration were carried out using a specific software (Chemstat 32, Scientific Software Group, Utah, USA). All the analyses were performed in triplicate and mean values and standard deviations were evaluated.

\subsubsection{Antioxidant Capacity}

DPPH Radical Scavenging Assay. Antioxidant capacity of coconut extracts was determined using the DPPH $(\alpha, \alpha$ Diphenyl- $\beta$-picryl-hydrazyl) radical scavenging assay by measuring the absorbance at $515 \mathrm{~nm}$ after 30 min of reaction at room temperature, as described by Brand-Williams et al. [22]. The results were expressed as $\mu \mathrm{mol} / \mathrm{g}$ of DM Trolox equivalents, using the calibration curve of Trolox (100$1000 \mu \mathrm{M})$. All measurements were performed in triplicate and mean values and standard deviations were evaluated.

ABTS Radical Scavenging Assay. Trolox equivalent antioxidant capacity (TEAC) of coconut extracts was estimated by the ABTS (2, $2^{\prime}$-azino-bis(3-ethylbenzothiazoline-6-sulphonic acid)) radical cation decolourisation assay [23]. 
The results, obtained from triplicate analyses, were expressed as Trolox equivalents in $\mu \mathrm{mol} / \mathrm{g}$ of DM and were derived from a calibration curve determined for this standard (100$1000 \mu \mathrm{M})$.

\subsection{Enzymatic Activity Determination}

2.8.1. Enzyme Extraction. Ground coconut (5 grams) was extracted at $4^{\circ} \mathrm{C}$ with a phosphate buffer solution $(0.1 \mathrm{M}$, $\mathrm{pH}$ 7) containing 5 grams of polyvinylpyrrolidone using a magnetic stirrer for $15 \mathrm{~min}$. The homogenate was filtered (Whatman No. 41 filter paper), centrifuged at $3500 \mathrm{rpm}$ for $20 \mathrm{~min}$ and subsequently the supernatant was filtered again (Whatman No. 42 filter paper) to collect enzyme extract [24].

2.8.2. Polyphenol Oxidase and Peroxidase (PPO and POD) Enzymatic Activity. Polyphenol oxidase (PPO) activity was determined using a spectrophotometric method based on the increase in absorbance at $410 \mathrm{~nm}$, according to the procedure described by Soliva et al. [25] with some modifications. Enzyme extract $(50 \mu \mathrm{L})$ was mixed with $1.95 \mathrm{~mL}$ of phosphate buffer solution and $1 \mathrm{~mL}$ of catechol $(0.1 \mathrm{M})$ in a $1 \mathrm{~cm}$ path length cuvette. The absorbance was continuously recorded at $25^{\circ} \mathrm{C}$ for $5 \mathrm{~min}$.

Peroxidase (POD) activity was assayed spectrophotometrically at $470 \mathrm{~nm}$ using guaiacol as a phenolic substrate with hydrogen peroxide [26]. The reaction mixture containing $0.15 \mathrm{~mL}$ of $4 \%(\mathrm{v} / \mathrm{v})$ guaiacol, $0.15 \mathrm{~mL}$ of $1 \%(\mathrm{v} / \mathrm{v}) \mathrm{H}_{2} \mathrm{O}_{2}$, $2.66 \mathrm{~mL}$ of phosphate buffer solution, and $40 \mu \mathrm{L}$ of enzyme extract was transferred to a $1 \mathrm{~cm}$ path length cuvette for the absorbance measurements. Enzyme activity was reported in enzyme Units $(U)$, defined as the change of 0.001 in the absorbance value per min under the conditions of the assay. Volume activity of both enzymes was calculated from the slope of the linear portion of the $\Delta A$ curve as a function of time according to the following formula:

$$
\mathrm{V} . \mathrm{a} .=\frac{\mathrm{VT}}{(\varepsilon \cdot d \cdot \mathrm{VE})} \cdot \frac{\Delta A}{\Delta t},
$$

where VT is for the total volume of the reaction mixture, $\mathrm{VE}$ the volume of the extracted enzyme, $d$ the cuvette path length $(1 \mathrm{~cm}), \varepsilon$ the molar absorptivity of 4-methylquinoline $\left(1010 \mathrm{M}^{-1} \mathrm{~cm}^{-1}\right)$ for PPO and tetraguaiacol (2.66 . $104 \mathrm{M}^{-1} \mathrm{~cm}^{-1}$ ) for POD, and $\Delta t$ the time interval. All measurements were performed in triplicate and the results were expressed as specific activity (S.a.) in enzyme units per g of product $(\mathrm{U} / \mathrm{g})$.

2.9. Sensory Analysis. Samples were evaluated by a panel of 10 untrained judges, 5 males and 5 females between 21 and 50 years old, using a descriptive analysis based on a modified procedure described by Komes et al. [27]. The evaluations were conducted the day after the samples preparation, in a quiet room with sufficient space between the testers, adequate light, and ventilation at mid-morning, considered the best time before extraneous aromas and odours fill the air. A rank order test was performed and the panelists were asked to

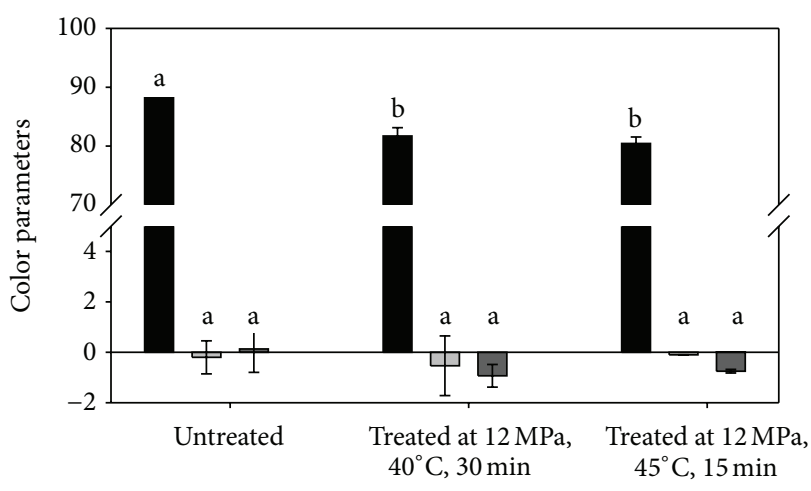

FIGURE 2: Color parameters of untreated and treated fresh-cut coconuts: lightness, $L^{*}$; light grey, $a^{*}$; dark grey, $b^{*}$. Values with similar letters within bars are not significantly different.

independently evaluate four sensory characteristics: appearance, texture, taste, and aroma for each sample, presented in plastic white cups at ambient temperature. The volunteers were asked to judge three samples using a 10-point scale (1 corresponded to the lowest preference and 10 to the highest): one untreated and two $\mathrm{SC}-\mathrm{CO}_{2}$ fresh-cut coconut treated at $12 \mathrm{MPa}, 40^{\circ} \mathrm{C}, 30 \mathrm{~min}$ and $12 \mathrm{MPa}, 45^{\circ} \mathrm{C}, 15 \mathrm{~min}$, respectively. The results were expressed as the average for each sensory attribute with the standard deviations.

2.10. Statistical Analysis. Differences between mean values were tested using the analysis of variance followed by multiple comparisons between means with the Tukey's Studentized Range test. The general procedure of Statistica 7.0 software (StatSoft Inc., Tulsa, OK, USA) was used. All the data were analyzed at a significance level of $P>0.05$.

\section{Discussion and Results}

3.1. Color. Figure 2 reports color measurements of untreated and $\mathrm{SC}-\mathrm{CO}_{2}$ treated coconuts. The results indicated that $a^{*}$ and $b^{*}$ parameters did not significantly change after treatments, while $L^{*}$ significantly decreased, in agreement with Ferrentino et al. [16] who found that $a^{*}$ and $b^{*}$ measured on coconut samples were approximately zero before and after processes at $12 \mathrm{MPa}, 40^{\circ} \mathrm{C}$, for 10,20 , and $30 \mathrm{~min}$, while $L^{*}$ significantly decreased just after $10 \mathrm{~min}$ of treatment. Color differences, in terms of $\Delta E$, were equal to 6.92 and to 8.15 for samples treated at $12 \mathrm{MPa}, 40^{\circ} \mathrm{C}, 30 \mathrm{~min}$ and at $12 \mathrm{MPa}$, $45^{\circ} \mathrm{C}, 15 \mathrm{~min}$, respectively, suggesting that a trained observer could detect visible differences between untreated and SC$\mathrm{CO}_{2}$ treated coconut. On the other hand, it must be said that the $\Delta E$ threshold value often depends on the type of matrix [28].

3.2. Titratable Acidity and $p H$. Table 1 reports $\mathrm{pH}$ and TA values of untreated and treated fresh-cut coconuts. A slight but significant $\mathrm{pH}$ decrease was observed: from 6.07 to 5.82 and 5.85 for samples treated at $12 \mathrm{MPa}, 40^{\circ} \mathrm{C}, 30 \mathrm{~min}$ and at $12 \mathrm{MPa}, 45^{\circ} \mathrm{C}, 15 \mathrm{~min}$, respectively. As expected, an opposite 
TABLE 1: pH, TA, DM, fat content, TPC, FC, and antioxidant capacity of untreated and $\mathrm{SC}-\mathrm{CO}_{2}$ treated coconut.

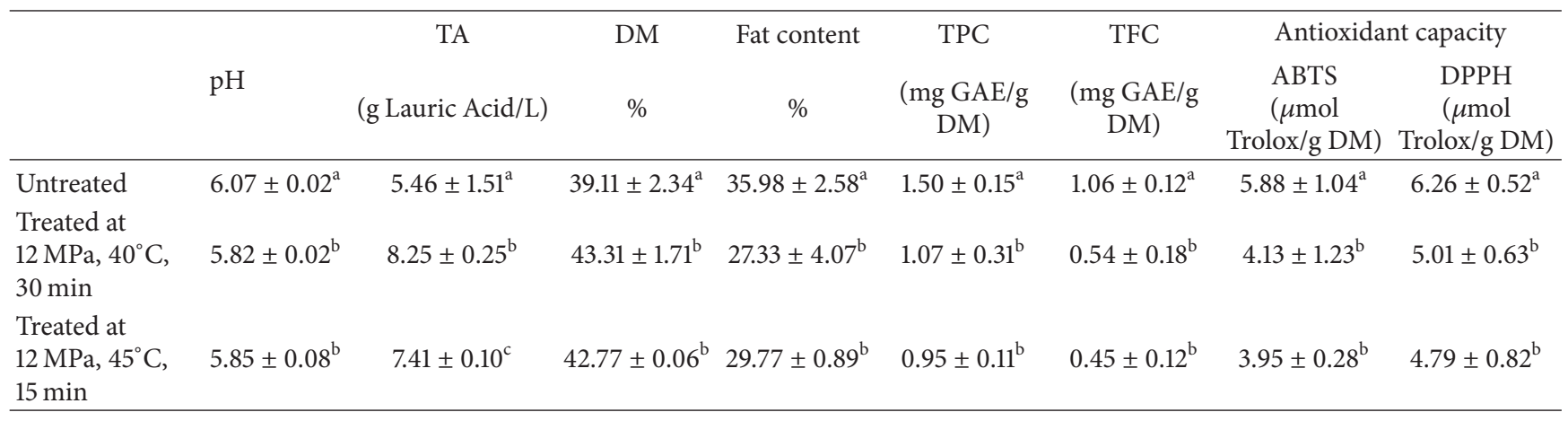

Data are mean values \pm standard deviations. Values with similar letters within rows are not significantly different $(P>0.05)$. TA: titratable acidity, DM: dry matter, TPC: total phenol content, TFC: total flavonoid content.

behavior was recorded for TA values. A similar trend has been already reported by other authors for TA measurements performed on liquid matrices processed by SC- $\mathrm{CO}_{2}[29,30]$. The increase in acidity could be related to the presence of $\mathrm{CO}_{2}$ dissolved into the liquid phase forming carbonic acid. Data were in agreement with another study on fresh-cut conference pears treated at $10 \mathrm{MPa}, 40^{\circ} \mathrm{C}, 10 \mathrm{~min}$ whose $\mathrm{pH}$ was unaffected by the treatment, while acidity increased [12].

3.3. Dry Matter and Fat Content. DM and fat content of untreated and $\mathrm{SC}-\mathrm{CO}_{2}$ treated coconut samples are reported in Table 1. DM of coconut ranged from $39.11 \pm 2.34 \%$ for untreated coconut to $43.31 \pm 1.71 \%$ and $42.77 \pm 0.06 \%$ for samples treated at $12 \mathrm{MPa}, 40^{\circ} \mathrm{C}, 30 \mathrm{~min}$ and $12 \mathrm{MPa}, 45^{\circ} \mathrm{C}, 15 \mathrm{~min}$ while fat content varied from $35.98 \pm 2.58 \%$ for the untreated to $27.33 \pm 4.07 \%$ and $29.77 \pm 0.89 \%$ for treated samples. As noticed, an opposite trend was observed comparing DM and fat content: fresh untreated coconuts were characterized by a lower DM and a higher fat content. DM increase in treated products could be related to water loss from the samples during the treatment while fat content decrease could be linked to $\mathrm{CO}_{2}$ high affinity for lipophilic substances that in supercritical phase exerts a high extractive power.

\subsection{Total Phenol Content, Flavonoid Content, and Antioxidant} Capacity. Higher TPC (1.495 $\pm 0.15 \mathrm{mg}$ GAE/g DM) and FC $(1.056 \pm 0.12 \mathrm{mg}$ GAE/g DM) were measured in the untreated coconut compared to the treated one, indicating some negative effects induced by $\mathrm{CO}_{2}$ on these beneficial bioactive compounds: on average $32 \%$ and $53 \%$ decrease in TPC and FC was observed after SC- $\mathrm{CO}_{2}$ treatments, respectively (Table 1). Additionally, also the antioxidant capacity, determined by both ABTS and DPPH assays, decreased in the treated samples (on average $31 \%$ by ABTS and $22 \%$ by DPPH) compared to the untreated ones. Published studies reported contrasting results regarding the effects of SC- $\mathrm{CO}_{2}$ treatment on total phenol content and antioxidant capacity in foods. Pozo-Insfran et al. [31] observed no changes in anthocyanins, soluble phenolics, and antioxidant capacity of muscadine grape juice processed by dense phase $\mathrm{CO}_{2}$ at $34.5 \mathrm{MPa}, 30^{\circ} \mathrm{C}$ for $6.25 \mathrm{~min}$. Similar conclusions were drafted by Ferrentino et al. [30] where no effects were observed on TPC of a red grapefruit juice treated by dense phase $\mathrm{CO}_{2}(34.5 \mathrm{MPa}$, $40^{\circ} \mathrm{C}, 7 \mathrm{~min}$ ) while slight differences were observed in the ascorbic acid content and antioxidant capacity of the juice after treatment and after 4 weeks of storage at $4^{\circ} \mathrm{C}$. On the contrary other studies demonstrated that vitamin $\mathrm{C}$ content of pears [12] and betanin and isobetanin contents of red beet [32] significantly decreased leading to the conclusion that SC$\mathrm{CO}_{2}$ treatment differently and selectively affected bioactive compounds probably depending on the characteristics of the food product. In the present study the decrease of polyphenolic compounds of coconut was attributed to the employed combination of high temperatures and long processing times of SC- $\mathrm{CO}_{2}$ treatment and to the increase in the food acidity due to the formation of carbonic acid which contributed to the modification and lowering contents of these compounds.

3.5. HPLC Determination of Phenolic Compounds. As reported in Table 2, ferulic acid was the most abundant compound detected in the sample (with a content of $60.93 \pm$ $3.48 \mu \mathrm{g} / \mathrm{g} \mathrm{DM}$ in the fresh untreated coconut and of $56.69 \pm$ $3.20 \mu \mathrm{g} / \mathrm{g}$ DM in the treated one at $12 \mathrm{MPa}, 45^{\circ} \mathrm{C}, 15 \mathrm{~min}$ ), followed by p-coumaric acid (from $55.74 \pm 1.45 \mu \mathrm{g} / \mathrm{gDM}$ in the untreated coconut to $48.13 \pm 1.56 \mu \mathrm{g} / \mathrm{g}$ DM in the treated one at $12 \mathrm{MPa}, 45^{\circ} \mathrm{C}, 15 \mathrm{~min}$ ) and chlorogenic acid (from $13.30 \pm 0.035 \mu \mathrm{g} / \mathrm{g}$ DM in the untreated coconut to $10.28 \pm$ $0.025 \mu \mathrm{g} / \mathrm{gDM}$ in the treated one at $12 \mathrm{MPa}, 45^{\circ} \mathrm{C}, 15 \mathrm{~min}$ ). The data obtained are in agreement with the ones obtained by Bankar et al. [33] even though in the present study much lower concentrations of all polyphenolic compounds were obtained, probably because of differences in coconut variety, degree of ripeness, geographical origin, or extraction technique. As a whole, from Table 2 it can be observed that fresh untreated coconut exhibited higher content of total polyphenolic compounds compared to treated samples. It could also be observed that vanillic acid was present only in the untreated sample, highlighting that $\mathrm{CO}_{2}$ treatments affected both content and composition of polyphenolic compounds. Compared to TPC results in Table 1, a much lower content of total phenolic acids was measured by HPLC analysis; this result was not surprising since it has been well established that spectrophotometric assays are not selective and often overestimate the results $[34,35]$. 
TABLE 2: Phenolic acids content of untreated and treated coconut extracts.

\begin{tabular}{|c|c|c|c|c|c|c|}
\hline & \multicolumn{5}{|c|}{ Phenolic acids ( $\mu \mathrm{g} / \mathrm{g} \mathrm{DM})$} & \multirow{2}{*}{ Total } \\
\hline & SA & VA & ChlA & $p$-coumA & FA & \\
\hline Untreated & $47.08 \pm 1.12^{\mathrm{a}}$ & $31.76 \pm 0.78$ & $13.30 \pm 0.035^{\mathrm{a}}$ & $55.74 \pm 1.45^{\mathrm{a}}$ & $60.93 \pm 3.48^{\mathrm{a}}$ & 208.81 \\
\hline Treated at $12 \mathrm{MPa}, 40^{\circ} \mathrm{C}, 30 \mathrm{~min}$ & $55.98 \pm 2.27^{\mathrm{b}}$ & n.d. ${ }^{*}$ & $12.97 \pm 0.011^{\mathrm{b}}$ & $59.75 \pm 2.65^{\mathrm{b}}$ & $55.47 \pm 2.91^{\mathrm{a}}$ & 184.17 \\
\hline Treated at $12 \mathrm{MPa}, 45^{\circ} \mathrm{C}, 15 \mathrm{~min}$ & $54.79 \pm 4.83^{\mathrm{b}}$ & n.d. ${ }^{*}$ & $10.28 \pm 0.025^{\mathrm{c}}$ & $48.13 \pm 1.56^{\mathrm{c}}$ & $56.69 \pm 3.20^{\mathrm{a}}$ & 169.89 \\
\hline
\end{tabular}

Data are mean values \pm standard deviations. Values with similar letters within rows are not significantly different $(P>0.05) .{ }^{*}$ Not detected. SA: syringic acid, VA: vanillic acid, ChlA: chlorogenic acid, $p$-coumA: $p$-coumaric acid, FA: ferulic acid.

TABLE 3: Enzymatic activity of untreated and SC- $\mathrm{CO}_{2}$ treated coconut.

\begin{tabular}{lcr}
\hline & PPO Activity $(\mathrm{U} / \mathrm{g})$ & POD activity $(\mathrm{U} / \mathrm{g})$ \\
\hline Untreated & $(10.440 \pm 0.001) \cdot 10^{-3 \mathrm{a}}$ & $(9.910 \pm 1.652) \cdot 10^{-3 \mathrm{a}}$ \\
Treated at $12 \mathrm{MPa}, 40^{\circ} \mathrm{C}, 30 \mathrm{~min}$ & $(7.594 \pm 1.687) \cdot 10^{-3 \mathrm{~b}}$ & $(17.620 \pm 0.001) \cdot 10^{-3 \mathrm{~b}}$ \\
Treated at $12 \mathrm{MPa}, 45^{\circ} \mathrm{C}, 15 \mathrm{~min}$ & $(0.202 \pm 0.081) \cdot 10^{-3 \mathrm{c}}$ & $(12.923 \pm 0.001) \cdot 10^{-3 \mathrm{c}}$ \\
\hline
\end{tabular}

Data are mean values \pm standard deviations. Values with similar letters within rows are not significantly different $(P>0.05)$. PPO: polyphenol oxidase, POD: peroxidase.

3.6. Polyphenol Oxidase and Peroxidase Activity. PPO and POD enzymatic activities of untreated and treated coconut samples are reported in Table 3. As noticed, both process conditions induced PPO inactivation: $35 \%$ and $98.5 \%$ inactivation was achieved at $12 \mathrm{MPa}, 40^{\circ} \mathrm{C}$, for $30 \mathrm{~min}$ and at $12 \mathrm{MPa}, 45^{\circ} \mathrm{C}$, for $15 \mathrm{~min}$, respectively.

According to the results, the combination of higher temperature $\left(45^{\circ} \mathrm{C}\right)$ and shorter processing time $(15 \mathrm{~min})$ is highly effective to inactivate PPO in coconut. The experimental findings are in agreement with Park et al. [36] who reported that PPO activity in carrot juice decreased after a combined high pressure $\mathrm{CO}_{2}$ and high hydrostatic pressure treatment. PozoInsfran et al. [37] also observed $40 \%$ decrease in PPO activity in muscadine grape juice by dense phase $\mathrm{CO}_{2}$ processing.

As regards POD, an increase of its activity was observed at both process conditions tested, as reported in Table 2: POD was activated by $77.8 \%$ at $12 \mathrm{MPa}, 40^{\circ} \mathrm{C}, 30 \mathrm{~min}$ and by $30.4 \%$ at $12 \mathrm{MPa}, 45^{\circ} \mathrm{C}, 15 \mathrm{~min}$. However, no off-flavors and offcolors of the sample were detected although these enzymes are supposed to be empirically related to the deterioration of fresh-cut vegetables and fruits [38]. Further, a storage study $\left(4^{\circ} \mathrm{C}\right.$ for 4 weeks) of the processed product was also performed and no enzymes reactivation, with consequently sample off-flavors and off-colors, was detected probably thanks to the low storage temperature employed in the study that was chosen considering the final use of the product as ready-to-eat fruit. The resistance of POD extracted from vegetables and fruits has been reported in several studies [39]: thermal processes $\left(\sim 90^{\circ} \mathrm{C}\right.$ for $\left.5 \mathrm{~s}\right)$ are needed to induce complete inactivation of this enzyme. Fricks et al. [40] performed a high pressure $\mathrm{CO}_{2}$ treatment on POD extracted from radish (Raphanus sativus L.) suspended in a buffer solution: an increase of the specific activity of this enzyme up to $212 \%$ was observed at $7 \mathrm{MPa}, 30^{\circ} \mathrm{C}$ and $1 \mathrm{hr}$ treatment. Further, Primo et al. [41] evaluated the effects of compressed $\mathrm{CO}_{2}$ treatment on the specificity of oxidase enzymatic complexes extracted from mate tea leaves: they showed that $30^{\circ} \mathrm{C}, 7.05 \mathrm{MPa}$ and $1 \mathrm{hr}$ treatment led to $25 \%$ enhancement of POD activity and $50 \%$ loss of PPO activity. Some literature results also demonstrated that POD residual activity was closely related to the $\mathrm{SC}-\mathrm{CO}_{2}$ applied pressure [42]: as the applied pressure was increased up to $30 \mathrm{MPa}$, the enzyme residual activity was reduced down to $12 \%$ indicating that the three-dimensional structure of enzymes could be significantly altered under extreme conditions, causing their denaturation and a consequent loss of their activity. If the conditions are less adverse, the protein structure could largely be retained. Minor structural changes could induce an alternative active protein state with altered enzyme activity, specificity, and stability [43]. However, to our knowledge, clear explanations and extensive investigations on the relationship between the activity of enzymes treated with supercritical fluids and supercritical operating conditions have never been provided.

3.7. Sensory Analyses. Panelists did not perceive significant differences in terms of appearance, texture, taste, and aroma attributes between untreated and treated samples (Table 4). Treated coconuts were judged similar to the fresh one, and no losses of product or discoloration of edible parts were observed. These results differed from the color instrumental measurements here reported, where significant differences in $L^{*}$ of the untreated and treated samples were detected and in $\Delta E$ values which indicated high overall color differences.

Concerning the texture, the panelists could not detect any noticeable differences between untreated and treated products: $\mathrm{SC}-\mathrm{CO}_{2}$ treated coconuts were judged firm, hard, and crispy and ranked sweet and harmonious with no detection of bitter or off-taste. These findings are also supported by the instrumental measurements performed to evaluate the hardness of fresh-cut coconut processed at the same $\mathrm{SC}-\mathrm{CO}_{2}$ conditions [14]. As regards aroma attributes and coconut like taste, the untreated fresh-cut coconut was rated with low scores indicating a higher panelists' preference towards the $\mathrm{SC}-\mathrm{CO}_{2}$ treated samples. Probably $\mathrm{CO}_{2}$ in supercritical state, acting in the extraction of volatile compounds associated to the flavor of fresh-cut coconut, had the ability to enhance the palatability and perception to 
TABLE 4: Sensory evaluations of fresh-cut coconut before and after $\mathrm{SC}-\mathrm{CO}_{2}$ treatments.

\begin{tabular}{|c|c|c|c|}
\hline & Untreated & Treated at $12 \mathrm{MPa}, 40^{\circ} \mathrm{C}, 30 \mathrm{~min}$ & Treated at $12 \mathrm{MPa}, 45^{\circ} \mathrm{C}, 15 \mathrm{~min}$ \\
\hline & \multicolumn{3}{|c|}{ Appearance } \\
\hline Product loss & $2.25 \pm 2.49^{\mathrm{a}}$ & $2.20 \pm 2.57^{\mathrm{a}}$ & $2.10 \pm 2.60^{\mathrm{a}}$ \\
\hline \multirow[t]{2}{*}{ Discoloration } & $2.60 \pm 2.26^{\mathrm{a}}$ & $2.7 \pm 1.95^{\mathrm{a}}$ & $2.30 \pm 1.77^{\mathrm{a}}$ \\
\hline & \multicolumn{3}{|c|}{ Texture } \\
\hline Crispy & $6.83 \pm 2.01^{\mathrm{a}}$ & $7.33 \pm 1.50^{\mathrm{a}}$ & $7.00 \pm 1.73^{\mathrm{a}}$ \\
\hline Hard & $6.95 \pm 2.44^{\mathrm{a}}$ & $6.60 \pm 2.22^{\mathrm{a}}$ & $6.80 \pm 1.87^{\mathrm{a}}$ \\
\hline Firmness & $7.30 \pm 2.08^{\mathrm{a}}$ & $7.40 \pm 1.07^{\mathrm{a}}$ & $7.20 \pm 1.32^{\mathrm{a}}$ \\
\hline Fracturability & $3.75 \pm 2.77^{\mathrm{a}}$ & $4.30 \pm 2.79^{\mathrm{a}}$ & $4.00 \pm 2.71^{\mathrm{a}}$ \\
\hline Grainy & $1.75 \pm 2.49^{\mathrm{a}}$ & $1.80 \pm 2.53^{\mathrm{a}}$ & $1.70 \pm 2.21^{\mathrm{a}}$ \\
\hline Fibrous & $5.40 \pm 3.45^{\mathrm{a}}$ & $5.30 \pm 3.56^{\mathrm{a}}$ & $5.20 \pm 3.36^{\mathrm{a}}$ \\
\hline \multirow[t]{2}{*}{ Moistness } & $3.35 \pm 2.70^{\mathrm{a}}$ & $4.60 \pm 1.96^{\mathrm{a}}$ & $3.80 \pm 2.44^{\mathrm{a}}$ \\
\hline & \multicolumn{3}{|c|}{ Taste } \\
\hline Coconut like & $6.45 \pm 2.28^{\mathrm{a}}$ & $7.00 \pm 2.21^{\mathrm{a}}$ & $6.10 \pm 2.18^{\mathrm{a}}$ \\
\hline Harmonious & $6.80 \pm 2.75^{\mathrm{a}}$ & $6.70 \pm 2.98^{\mathrm{a}}$ & $6.10 \pm 2.51^{\mathrm{a}}$ \\
\hline Sweet & $5.10 \pm 2.40^{\mathrm{a}}$ & $5.40 \pm 2.32^{\mathrm{a}}$ & $5.00 \pm 2.32^{\mathrm{a}}$ \\
\hline Bitter & $1.10 \pm 0.31^{\mathrm{a}}$ & $1.50 \pm 0.85^{\mathrm{a}}$ & $1.40 \pm 1.40^{\mathrm{a}}$ \\
\hline \multirow[t]{2}{*}{ Off taste } & $1.15 \pm 0.49^{\mathrm{a}}$ & $1.30 \pm 0.67^{\mathrm{a}}$ & $1.40 \pm 0.84^{\mathrm{a}}$ \\
\hline & \multicolumn{3}{|c|}{ Aroma } \\
\hline Fresh coconut & $3.85 \pm 2.11^{\mathrm{a}}$ & $5.10 \pm 2.33^{\mathrm{a}}$ & $4.40 \pm 2.50^{\mathrm{a}}$ \\
\hline Nutty & $1.65 \pm 1.73^{\mathrm{a}}$ & $1.90 \pm 1.91^{\mathrm{a}}$ & $2.20 \pm 2.20^{\mathrm{a}}$ \\
\hline Rancid & $1.65 \pm 2.01^{\mathrm{a}}$ & $1.60 \pm 1.26^{\mathrm{a}}$ & $1.20 \pm 0.63^{\mathrm{a}}$ \\
\hline Off odor & $1.85 \pm 1.76^{\mathrm{a}}$ & $1.80 \pm 1.48^{\mathrm{a}}$ & $1.60 \pm 1.35^{\mathrm{a}}$ \\
\hline
\end{tabular}

Data are mean values \pm standard deviations. Values with similar letters within rows are not significantly different $(P>0.05)$.

the panelists of these compounds. A study published by Ji et al. [13] also demonstrated that the color modifications of shrimps induced by SC- $\mathrm{CO}_{2}$ treatment positively influenced panelist's decision who attributed higher grade scores to treated shrimps compared to the untreated.

Overall, the results presented in this study clearly demonstrated that $\mathrm{SC}-\mathrm{CO}_{2}$ treatments did not influence the organoleptic attributes of the product highlighting the acceptability of the product by the consumers.

\section{Conclusions}

The present work provided scientific data on the effects of SC$\mathrm{CO}_{2}$ on the quality aspects of fresh-cut coconut. Both SC$\mathrm{CO}_{2}$ process conditions $\left(12 \mathrm{MPa}, 40^{\circ} \mathrm{C}, 30 \mathrm{~min}\right.$ and $12 \mathrm{MPa}$, $45^{\circ} \mathrm{C}, 15 \mathrm{~min}$ ) influenced product attributes: color slightly changed, and fat content, TPC, $\mathrm{pH}$, and antioxidant capacity decreased while DM and TA increased. As regards enzymatic activity, the results showed that POD activity increased and PPO activity was reduced. Although complete inactivation was not achieved, the product was not prone to enzymatic off-flavors and off-colors. Sensorial analyses showed that panelists could not detect any significant differences in terms of texture, taste, appearance, and aroma; however, color instrumental analyses reported significant differences in lightness between the untreated and treated samples. In conclusion, the results of this work together with the findings of microbial inactivation previously published [14] highlight the potentials of $\mathrm{SC}-\mathrm{CO}_{2}$ pasteurization of solid ready-to-eat products with firm structure. Nevertheless, further studies are needed to investigate the application of the technology on other products, looking at microbiological as well as nutritional aspects. Additionally, in view of a possible exploitation at industrial level, both an economic feasibility and design and scale-up studies are needed to develop a continuous plant to integrate in the existing process lines.

\section{Acknowledgments}

The research leading to these results received funding from the European Community's Seventh Framework Program (FP7/2007-2013) under Grant Agreement no. 245280, also known with the acronym PRESERF "Processing Raw Materials into Excellent and Sustainable End products while Remaining Fresh." The authors are grateful to Sara Balzan for her help in carrying out the experimental runs.

\section{References}

[1] X. Bi, J. Wu, Y. Zhang, Z. Xu, and X. Liao, "High pressure carbon dioxide treatment for fresh-cut carrot slices," Innovative Food Science and Emerging Technologies, vol. 12, no. 3, pp. 298-304, 2011.

[2] M. Sinigaglia, M. R. Corbo, D. D’Amato, D. Campaniello, and C. Altieri, "Shelf-life modelling of ready-to-eat coconut," International Journal of Food Science and Technology, vol. 38, no. 5, pp. 547-552, 2003. 
[3] T. Ohlsson, "Minimal processing-preservation methods of the future: an overview," Trends in Food Science and Technology, vol. 5, no. 11, pp. 341-344, 1994.

[4] B. J. Jennylynd and N. Tipvanna, "Processing of fresh-cut tropical fruits and vegetables: a technical guide," in Rap Publication, R. S. Rolle, Ed., vol. 16, pp. 1-84, Food and Agriculture Organization of the United Nations Regional Office for Asia and the Pacific, Bangkok, Thailand, 2001.

[5] Y. Tatsumi, A. E. Watada, and P. P. Ling, "Sodium chloride treatment or waterjet slicing effects on white tissue development of carrot sticks," Journal of Food Science, vol. 58, pp. 1390-1392, 1993.

[6] L. R. Howard, L. E. Griffin, and Y. Lee, "Steam treatment of minimally processed carrot sticks to control surface discoloration," Journal of Food Science, vol. 59, pp. 356-358, 1994.

[7] H. R. Bolin, "Retardation of surface lignification on fresh peeled carrots," Journal of Food Processing and Preservation, vol. 16, pp. 99-104, 1992.

[8] A. Amanatidou, R. A. Slump, L. G. M. Gorris, and E. J. Smid, "High oxygen and high carbon dioxide modified atmospheres for shelf-life extension of minimally processed carrots," Journal of Food Science, vol. 65, no. 1, pp. 61-66, 2000.

[9] S. Damar and M. O. Balaban, "Review of dense phase $\mathrm{CO}_{2}$ technology: microbial and enzyme inactivation, and effects on food quality," Journal of Food Science, vol. 71, no. 1, pp. R1-R11, 2006.

[10] G. Ferrentino and S. Spilimbergo, "High pressure carbon dioxide pasteurization of solid foods: current knowledge and future outlooks," Trends in Food Science and Technology, vol. 22, no. 8, pp. 427-441, 2011.

[11] C. I. Wei, M. O. Balaban, S. Y. Fernando, and A. J. Peplow, "Bacterial effect of high pressure $\mathrm{CO}_{2}$ treatment on foods spiked with Listeria or Salmonella," Journal of Food Protection, vol. 54, pp. 189-193, 1991.

[12] M. T. Valverde, F. Marín-Iniesta, and L. Calvo, "Inactivation of Saccharomyces cerevisiae in conference pear with high pressure carbon dioxide and effects on pear quality," Journal of Food Engineering, vol. 98, no. 4, pp. 421-428, 2010.

[13] H. Ji, L. Zhang, S. Liu, X. Qu, C. Zhang, and J. Gao, “Optimization of microbial inactivation of shrimp by dense phase carbon dioxide," International Journal of Food Microbiology, vol. 156, no. 1, pp. 44-49, 2012.

[14] G. Ferrentino, S. Balzan, A. Dorigato, A. Pegoretti, and S. Spilimbergo, "Effect of supercritical carbon dioxidepasteurization on natural microbiota, texture and microstructure of freshcut coconut," Journal of Food Science, vol. 77, no. 5, pp. E137E143, 2012.

[15] R. Hunter and R. W. Harold, The Measurement of Appearance, chapter 11, John Wiley \& Sons, New York, NY, USA, 2nd edition, 1975.

[16] G. Ferrentino, S. Balzan, and S. Spilimbergo, "On-line color monitoring of solid foods during supercritical $\mathrm{CO}_{2}$ pasteurization," Journal of Food Engineering, vol. 110, no. 1, pp. 80-85, 2012.

[17] Association of Official Analytical Chemists (AOAC), Official Methods of Analysis, AOAC International, Baltimore, Md, USA, 16th edition, 1995.

[18] ISO 659, "Determination of oil content," (Reference method), 1998.

[19] J. Lachman, V. Hosnedl, V. Pivec, and M. Orsák, "Polyphenols in cereals and their positive and negative role in human and animal nutrition," in Proceedings of Conference Cereals for Human Health and Preventive Nutrition, pp. 118-125, 1998.
[20] T. E. Kramling and V. E. Singleton, "An estimate of the nonflavonoid phenols in wines," American Journal of Enology \& Viticulture, vol. 20, pp. 86-92, 1969.

[21] IOOC, "Determination of biophenols in olive oils by HPLC," 2008, http://www.internationaloliveoil.org/web/aa-ingles/

corp/AreasActivitie/economics/Areas_Activitie.html.

[22] W. Brand-Williams, M. E. Cuvelier, and C. Berset, "Use of a free radical method to evaluate antioxidant activity," LebensmittelWissenschaft und-Technologie, vol. 28, no. 1, pp. 25-30, 1995.

[23] R. Re, N. Pellegrini, A. Proteggente, A. Pannala, M. Yang, and C. Rice-Evans, "Antioxidant activity applying an improved ABTS radical cation decolorization assay," Free Radical Biology and Medicine, vol. 26, no. 9-10, pp. 1231-1237, 1999.

[24] P. Arnnok, C. Ruangviriyachai, R. Mahachai, S. Techawongstien, and S. Chanthai, "Optimization and determination of polyphenol oxidase and peroxidase activities in hot pepper (Capsicum annuum L.) pericarb," International Food Research Journal, vol. 17, no. 2, pp. 385-392, 2010.

[25] R. C. Soliva, P. Elez, M. Sebastián, and O. Martín, "Evaluation of browning effect on avocado purée preserved by combined methods," Innovative Food Science and Emerging Technologies, vol. 1, no. 4, pp. 261-268, 2000.

[26] J. Díaz, A. Bernal, F. Pomar, and F. Merino, "Induction of shikimate dehydrogenase and peroxidase in pepper (Capsicum annuum L.) seedlings in response to copper stress and its relation to lignification," Plant Science, vol. 161, no. 1, pp. 179$188,2001$.

[27] D. Komes, A. Belščak-Cvitanović, D. Horžić, H. Drmić, S. Škrabal, and B. Miličević, "Bioactive and sensory properties of herbal spirit enriched with cocoa (Theobroma cacao L.) polyphenolics," Food Bioprocess Technology, vol. 5, no. 7, pp. 2908-2920, 2012.

[28] T. Koksal and I. Dikbas, "Color stability of different denture teeth materials against various staining agents," Dental Materials Journal, vol. 27, no. 1, pp. 139-144, 2008.

[29] D. Kincal, W. S. Hill, M. Balaban et al., "A continuous highpressure carbon dioxide system for cloud and quality retention in orange juice," Journal of Food Science, vol. 71, no. 6, pp. C338C344, 2006.

[30] G. Ferrentino, M. L. Plaza, M. Ramirez-Rodrigues, G. Ferrari, and M. O. Balaban, "Effects of dense phase carbon dioxide pasteurization on the physical and quality attributes of a red grapefruit juice," Journal of Food Science, vol. 74, no. 6, pp. E333E341, 2009.

[31] D. D. Pozo-Insfran, M. O. Balaban, and S. T. Talcott, "Microbial stability, phytochemical retention, and organoleptic attributes of dense phase $\mathrm{CO}_{2}$ processed muscadine grape juice," Journal of Agricultural and Food Chemistry, vol. 54, no. 15, pp. 54685473, 2006.

[32] X. Liu, Y. Gao, H. Xu, Q. Hao, G. Liu, and Q. Wang, "Inactivation of peroxidase and polyphenol oxidase in red beet (Beta vulgaris L.) extract with continuous high pressure carbon dioxide," Food Chemistry, vol. 119, no. 1, pp. 108-113, 2010.

[33] G. R. Bankar, P. G. Nayak, P. Bansal et al., "Vasorelaxant and antihypertensive effect of Cocos nucifera Linn. endocarp on isolated rat thoracic aorta and DOCA salt-induced hypertensive rats," Journal of Ethnopharmacology, vol. 134, no. 1, pp. 50-54, 2011.

[34] A. Escarpa and M. C. Gonzalez, "An overview of analytical chemistry of phenolic compounds in foods," Critical Reviews in Analytical Chemistry, vol. 31, no. 2, pp. 57-139, 2001. 
[35] J. A. Vinson, X. Su, L. Zubik, and P. Bose, "Phenol antioxidant quantity and quality in foods: fruits," Journal of Agricultural and Food Chemistry, vol. 49, no. 11, pp. 5315-5321, 2001.

[36] S.-J. Park, J.-I. Lee, and J. Park, "Effects of a combined process of high-pressure carbon dioxide and high hydrostatic pressure on the quality of carrot juice," Journal of Food Science, vol. 67, no. 5, pp. 1827-1834, 2002.

[37] D. D. Pozo-Insfran, M. O. Balaban, and S. T. Talcott, "Inactivation of polyphenol oxidase in muscadine grape juice by dense phase- $\mathrm{CO}_{2}$ processing," Food Research International, vol. 40, no. 7, pp. 894-899, 2007.

[38] F. S. Burnette, "Peroxidase and its relationship to food flavour and quality. A review," Journal of Food Science, vol. 42, pp. 1-6, 1977.

[39] E. M. Gonçalves, J. Pinheiro, M. Abreu, T. R. S. Brandão, and C. L. M. Silva, "Carrot (Daucus carota L.) peroxidase inactivation, phenolic content and physical changes kinetics due to blanching," Journal of Food Engineering, vol. 97, no. 4, pp. 574-581, 2010.

[40] A. T. Fricks, D. P. B. Souza, E. G. Oestreicher et al., "Evaluation of radish (Raphanus sativus L.) peroxidase activity after highpressure treatment with carbon dioxide," The Journal of Supercritical Fluids, vol. 38, no. 3, pp. 347-353, 2006.

[41] M. S. Primo, G. C. Ceni, N. S. Marcon et al., "Effects of compressed carbon dioxide treatment on the specificity of oxidase enzymatic complexes from mate tea leaves," The Journal of Supercritical Fluids, vol. 43, no. 2, pp. 283-290, 2007.

[42] F. Gui, F. Chen, J. Wu, Z. Wang, X. Liao, and X. Hu, "Inactivation and structural change of horseradish peroxidase treated with supercritical carbon dioxide," Food Chemistry, vol. 97, no. 3, pp. 480-489, 2006.

[43] M. Habulin and Z. Knez, "Activity and stability of lipases from different sources in supercritical carbon dioxide and near-critical propane," Journal of Chemical Technology and Biotechnology, vol. 76, no. 12, pp. 1260-1266, 2001. 

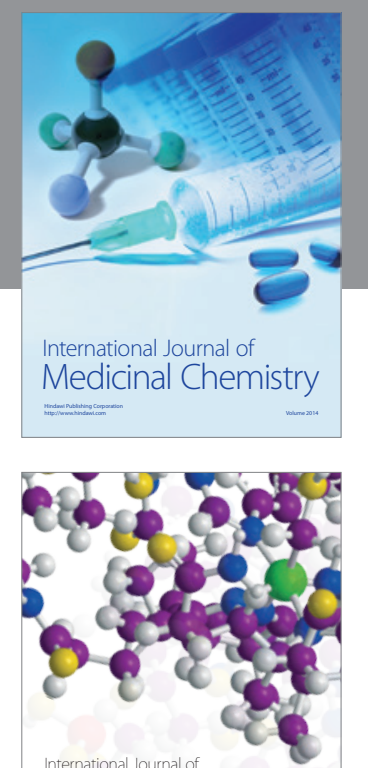

\section{Carbohydrate} Chemistry

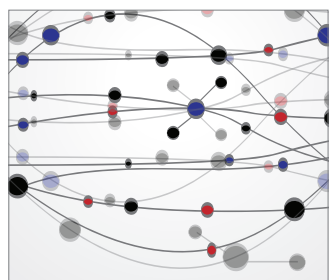

The Scientific World Journal
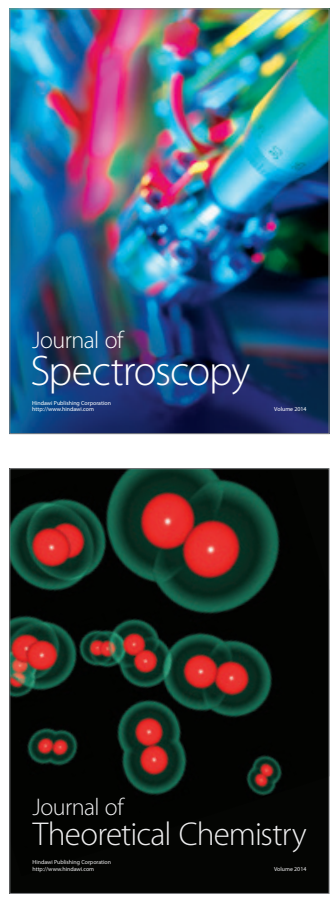
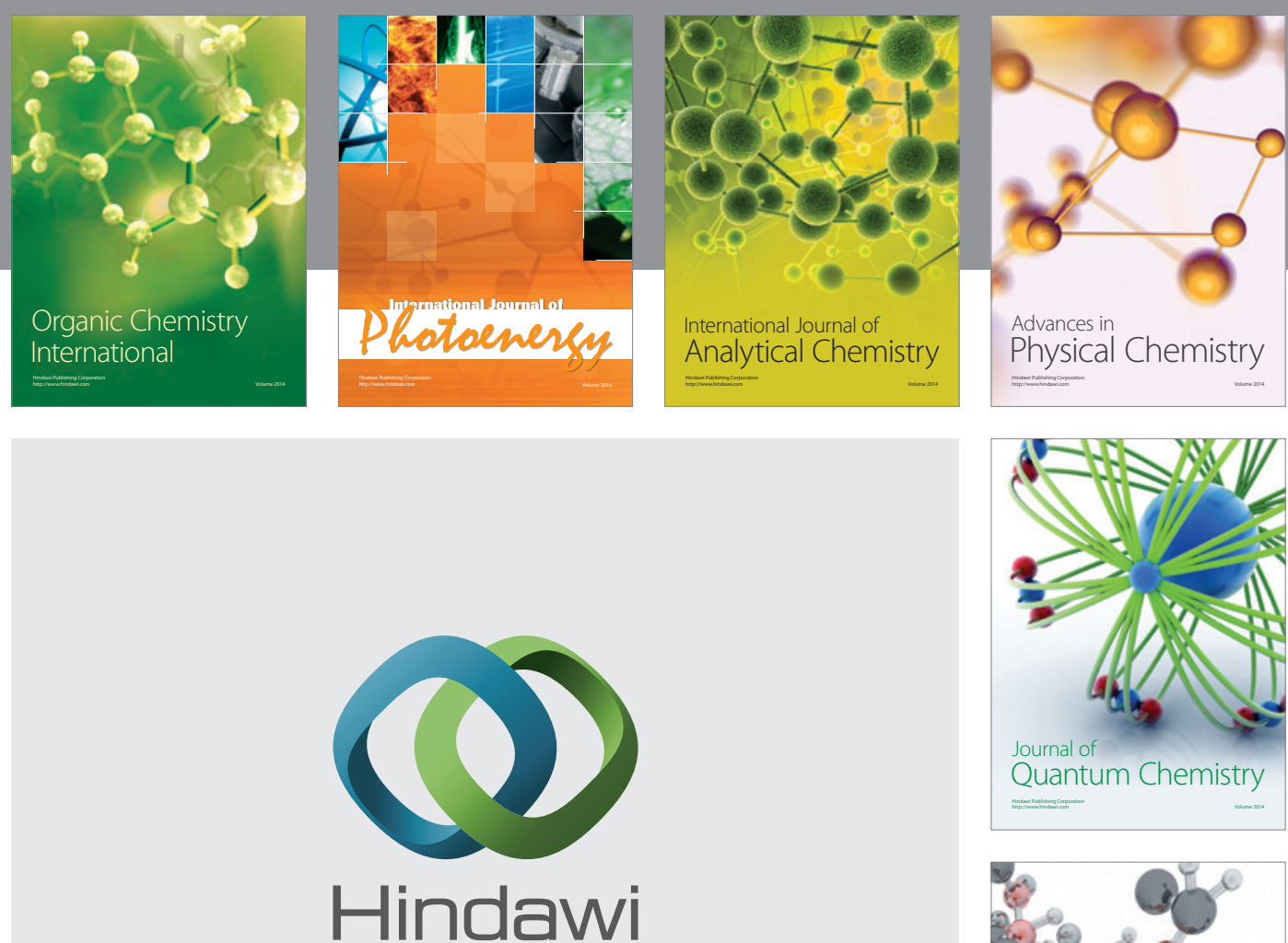

Submit your manuscripts at

http://www.hindawi.com

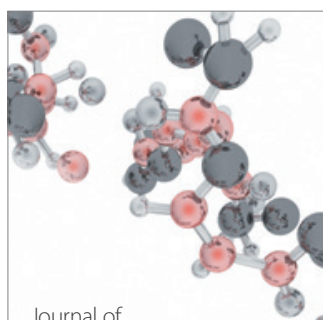

Analytical Methods

in Chemistry

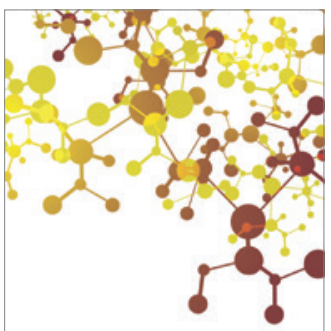

Journal of

Applied Chemistry

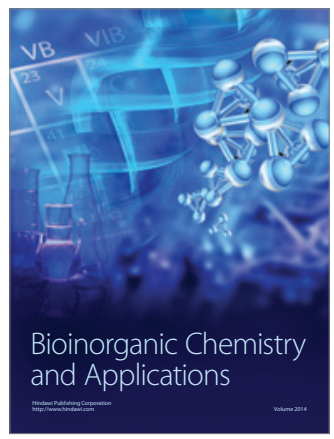

Inorganic Chemistry
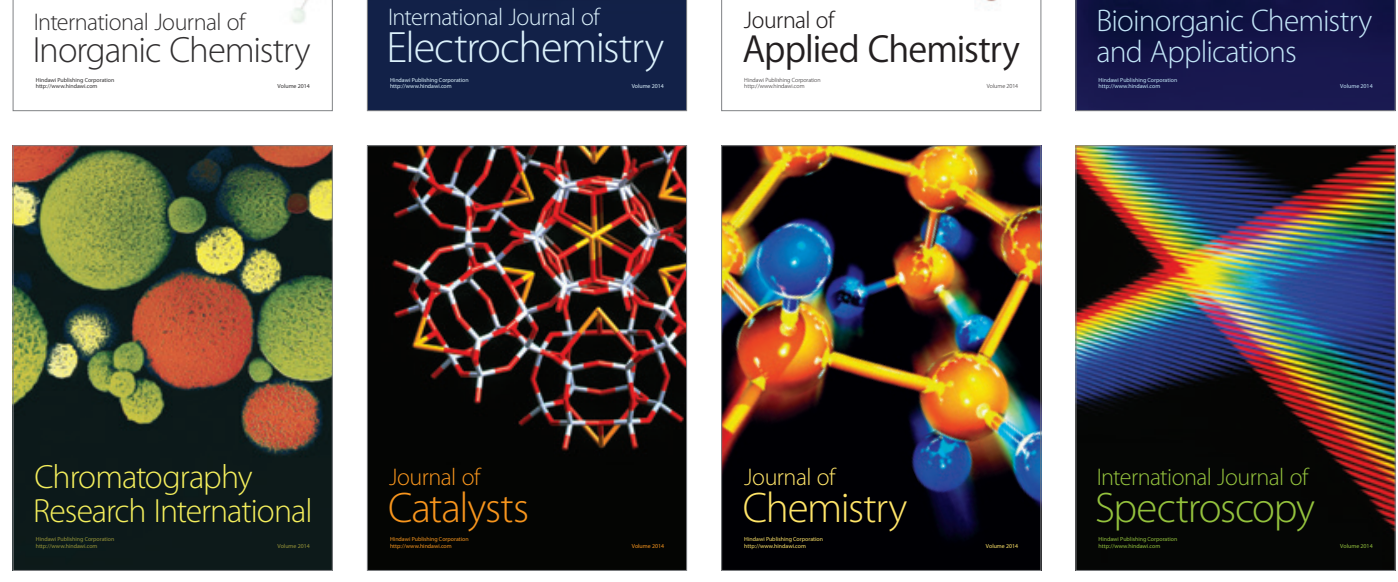